\title{
The Occurrence of Natural Antibodies to Rumen Bacteria
}

\author{
By M. ELISABETH SHARPE, M. J. LATHAM AND B. REITER \\ National Institute for Research in Dairying, \\ Shinfield, Reading, Berkshire
}

(Accepted for publication I9 February 1969)

\begin{abstract}
SUMMARY
The sera of I I ruminants and one horse contained relatively high titres of agglutinating antibodies against strains of anaerobic bacteria isolated from the bovine rumen. They were not detected in the sera of non-ruminants, i.e. pig, rabbit, guinea pig, rat and man. A close relationship existed between motility of rumen organisms and their ability to evoke detectable antibodies, although antibodies to both flagellar and somatic antigens were produced. The antibodies to the rumen organisms were highly specific and of the $\operatorname{IgM}$ type. They occurred in bovine colostrum at the same level as in the blood serum, and were transferred to the calf via the colostrum. After I month they had disappeared from the calf serum but between 5 and 8 months later antibodies of a similar activity were detected. In addition, antibodies to the non-motile Bifidobacterium bifidus were found in the sera of the young calf.
\end{abstract}

\section{INTRODUCTION}

In the absence of infection or overt stimulation with exogenous antigens, antibodies have been demonstrated in the sera of animals and man which are regarded as natural antibodies (Boyden, I966). The intestinal flora is considered to be the most important source of antigenic stimulation for the production of such antibodies, providing a small but unremitting source of antigens.

Attempts have been made to define patterns of natural antibodies against Enterobacteriaceae (Gibson, I930; Landy \& Weidanz, I964) amongst the sera of different animal species. Although it was not possible to make clear-cut distinctions between the animals, there were indications that each species might have its own pattern. It has been suggested (Reiter \& Oram, 1967) that in ruminants conditions are particularly favourable for the formation of natural antibodies from rumen organisms. The specialization and high concentrations of organisms within the rumen might give rise to a greater specificity and to a higher titre of antibodies in the sera of these animals.

This paper is concerned with agglutination titres in bovine sera against anaerobic rumen bacteria, the patterns of antibody reactions of different animal sera against these organisms, and the appearance of such antibodies in the bovine colostrum and their transfer to the calf serum.

\section{METHODS}

Samples of well-mixed rumen contents were removed from a fistulated cow (A), and organisms isolated by the anaerobic techniques of Hungate (I950). Primary 
isolation was made in roll tubes using a slightly modified medium ro of Caldwell \& Bryant (1966). Two stock mineral solutions were prepared (I) $\mathrm{K}_{2} \mathrm{HPO}_{4} 0.6 \% \mathrm{w} / \mathrm{v}$; (2) $\mathrm{NaCl} \mathrm{I} \cdot 2 \%,\left(\mathrm{NH}_{4}\right)_{2} \mathrm{SO}_{4} \mathrm{I} \cdot 2 \%, \mathrm{KH}_{2} \mathrm{PO}_{4} 0 \cdot 6 \%, \mathrm{CaCl}_{2} \mathrm{O} \cdot 12 \%, \mathrm{MgSO}_{4} 7 \mathrm{H}_{2} \mathrm{O} 0 \cdot 25 \%$, and a stock mixture of volatile fatty acids: acetic $17 \mathrm{ml}$, propionic $6 \mathrm{ml}$, $n$-butyric $4 \mathrm{ml}$, , isobutyric I ml., DL- $\alpha$-methyl- $n$-butyric $\mathrm{I} \mathrm{ml}$,, isovaleric I $\mathrm{ml}$., $n$-valeric, I $\mathrm{ml}$. The composition of the medium was as follows ( $\% \mathrm{w} / \mathrm{v}$ final concentration): glucose, 0.05 ; cellobiose, 0.05 ; soluble starch, 0.05 ; maltose, 0.05 ; yeast extract, 0.05 ; trypticase, 0.2 ; resazurin, $0.000 \mathrm{I}$; haemin, $0.000 \mathrm{I}$; agar, 2.0 ; cysteine- $\mathrm{HCl}$ and sodium sulphide each, 0.015 ; sodium carbonate, 0.4 ; volatile fatty acid mixture, $0.45(\mathrm{v} / \mathrm{v})$; mineral solutions I and $2,7.5(\mathrm{v} / \mathrm{v})$ each; adjusted to $\mathrm{pH} 6.7$ to 6.8 with $\mathrm{N}-\mathrm{NaOH}$. The cysteine- $\mathrm{HCl}+$ sodium sulphide mixture and the sodium carbonate were added separately as sterile solutions to the freshly autoclaved medium. Cleland's reagent, a protective reagent for $\mathrm{SH}$ groups (Cleland, 1964), was also added (to a final concentration $0.000 \mathrm{I} \mathrm{M}$ ) in some instances to help poise the medium at the low Eh value required for growth of some of the rumen organisms. Further cultivation was done on agar slopes and in broth of a similar composition but containing $0.2 \%, \mathrm{w} / \mathrm{v}$, each of glucose, cellobiose and maltose and without starch (medium Mro).

All media distribution and cultural work was done in an atmosphere of oxygen-free $\mathrm{CO}_{2}$.

Isolations and counts of total viable organisms were made from 3 rumen samples taken before, and I and $\mathrm{I} 4$ days after, a change of diet from $100 \%$ hay to $100 \%$ flaked maize.

Sample No.
$\mathbf{I T}$
$2 \mathbf{T}$
$7 \mathbf{T}$

Cows' diet
$100 \%$ hay
$100 \%$ flaked maize
$100 \%$ flaked maize

Viable organisms/g. rumen contents

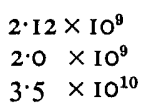

Colonies were picked from appropriate roll tubes onto slopes of medium Mio, were cultured in Mio broth and preserved on slopes of Mro at $-60^{\circ}$.

Isolation of Escherichia coli. These organisms were isolated from the rumen contents of two cows $\mathrm{B}$ and $\mathrm{C}$ on $100 \%$ hay diet, using conventional anaerobic conditions (McIntosh \& Fildes jar) and MacConkey media. Counts were estimated by mean probable numbers (m.p.n.), and were positive at ${ }_{10} 0^{-3}$ dilutions of rumen contents, but not at $10^{-4}$.

Laboratory strains of Enterobacteriaceae. Six human strains of Escherichia coli NCTC 8603, 9026, 9703, 9705, 9707, 9855. Ten strains of Klebsiella aerogenes isolated previously from bovine mastitis cases and from straw bedding by Dr C. M. Cousins (N.I.R.D.).

\section{Identification of organisms}

Anaerobic rumen bacteria. Isolates were presumptively classed in a number of genera and species by morphology, motility, Gram reaction, production of gas from glucose, final $\mathrm{pH}$ value in glucose broth, $\mathrm{H}_{2} \mathrm{~S}$ production and breakdown of cellulose and starch (Hungate, 1966). Lactobacilli were identified by physiological and biochemical tests (Sharpe, Fryer \& Smith, I966), using media containing $0.02 \%$ $(\mathrm{w} / \mathrm{v})$ cysteine and anaerobic cultivation by conventional anaerobic methods. The tests described by Shattock (1963) were used to identify Streptococcus bovis; Escherichia coli strains were identified by morphology and IMVIC tests. 


\section{Serological tests}

Suspensions for agglutination tests. Anaerobic organisms were grown for $18 \mathrm{hr}$ anaerobically in $100 \mathrm{ml}$. medium MIo, centrifuged, washed and half the organisms suspended in $0.85 \%$ saline $+0.2 \%$ formaldehyde. The other half was suspended in $0.85 \%$ saline and heated to $100^{\circ}$ for $\mathrm{I} \mathrm{hr}$ to destroy flagellar antigens. Extinctions were adjusted to a value of 0.55 ( $\mathrm{I} \mathrm{cm}$. cell, filter $\left.5^{8}\right)$ on the Hilger Biochem. Absorptiometer. Lactobacilli were grown anaerobically in medium MRS (de Man, Rogosa \& Sharpe, 1960$)+0.02 \%$ (w/v) cysteine; Escherichia coli and Streptococcus bovis were grown aerobically in yeast glucose broth. All cultures were divided into two portions and suspensions treated in a similar manner to those of the anaerobic bacteria.

Agglutination tests. Results were read after overnight incubation at $50^{\circ}$.

Agglutinin absorption tests. Sera were absorbed with an equal volume of formol treated or heat-treated $\left(100^{\circ}\right.$ for $\mathrm{I} \mathrm{hr}$ ) bacterial suspensions (extinction I.4, I cm. cell filter 58$)$.

Animal sera. Sera were obtained from: cows A, B, C and D (fistulated experimental cows); cow $\mathrm{E}$ from a different part of the country; cows F, G and $\mathrm{H}$ from the Institute herd; two goats from the Institute herd, housed and kept quite separately from the cows; one rabbit, one guinea pig, two rats, one pig (all Institute experimental animals); one sheep and one horse from a different part of the country. Sera were preserved with $0.01 \% \mathrm{w} / \mathrm{v}$ thiomersalate and stored at $-20^{\circ}$.

Preparation of antisera in rabbits. Rabbits were inoculated intravenously every 3 to 4 days with an $18 \mathrm{hr}$ culture of washed formaldehyde-treated organisms for a course of eight injections.

Transfer of naturally occurring antibodies from cow to calf. Samples of sera and of the secretion of the non-lactating udders were taken from three cows three weeks before parturition. In addition samples of the first colostrum, of the milk 3 weeks after calving and of the cows' sera 6 weeks after calving were examined. Serum was taken from each calf before the first feed with colostrum and at monthly intervals for 9 months.

Gel filtration. Cow serum and colostrum were filtered on Sephadex G-200, equilibrated with $0.1 \mathrm{M}-\mathrm{KCl}+0.0 \mathrm{I} \mathrm{M}$-tris buffer $+\mathrm{HCl},\left(\mathrm{pH}_{7} \cdot 5\right)$.

\section{RESULTS}

Agglutination titres of anaerobic rumen bacteria in serum of cow A

Table I shows the agglutination reactions of 70 rumen strains isolated from cow A, when titres as high as 320 were sometimes obtained. The close correlation between motility of an organism and its ability to react with the antibodies in the serum can be seen. Agglutinins to flagellar antigens were detected in 37 of the strains and agglutinins to somatic antigens in 17 out of 38 strains examined. With the non-motile strains practically no agglutination reactions were observed. Three strains of nonmotile lactobacilli were not agglutinated whereas a relatively high titre was present against the motile strain. 
Agglutination titres of anaerobic rumen organisms with sera of different animals

Some of the rumen isolates from cow A were then tested against the sera of five other cows, two goats, rabbit, two rats, pig, horse and sheep (Table 2). The sheep, one cow and the horse were from different environments, the other sera came from animals housed at the Institute. The same organisms were agglutinated in a similar pattern and to similar titres against both flagellar and somatic antigens with the sera of the cows, the goats, the sheep and the horse. The sera of the other animals however showed only an occasional weak reaction with rumen organisms.

Table I. Agglutination reactions of rumen bacteria isolated from cow $A$ with serum from cow $A$

\begin{tabular}{|c|c|c|c|c|c|c|}
\hline \multirow[b]{2}{*}{ Genus or species } & \multicolumn{3}{|c|}{ Formol-treated organisms } & \multicolumn{3}{|c|}{ Heat-treated organisms } \\
\hline & $\begin{array}{c}\text { No. of } \\
\text { strains } \\
\text { examined }\end{array}$ & $\begin{array}{c}\text { No. of } \\
\text { strains } \\
\text { in which } \\
\text { motility } \\
\text { observed }\end{array}$ & Titres & $\begin{array}{l}\text { No. of } \\
\text { strains }\end{array}$ & $\begin{array}{l}\text { No. of } \\
\text { strains } \\
\text { in which } \\
\text { motility } \\
\text { observed }\end{array}$ & Titres \\
\hline Butyrivibrio & 15 & 14 & $40-320$ & 7 & 7 & $40-160$ \\
\hline Selenomonas & 12 & 12 & $40-160$ & 6 & 6 & $20-80$ \\
\hline Bacteroides & I 2 & 0 & $<20$ & 7 & 0 & $<20$ \\
\hline Streptococcus bovis & IO & 0 & $<20$ & 8 & o & $<20$ \\
\hline Streptococcus bovis & 2 & 0 & $20-40$ & . & . & . \\
\hline Lactobacillus & 3 & 0 & $<20$ & 3 & 0 & $<20$ \\
\hline Lactobacillus & I & I & 160 & I & $\mathbf{I}$ & 80 \\
\hline Ruminococcus & 2 & 0 & $<20$ & I & 0 & $<20$ \\
\hline Spirillum & $\mathbf{I}$ & I & 20 & . & . & · \\
\hline Succinivibrio & I & I & 80 & . & . & . \\
\hline Lachnospira & I & if & 80 & $\mathbf{I}$ & I & 40 \\
\hline Unclassified & 8 & 7 & $20-160$ & 2 & 2 & $20-40$ \\
\hline Unclassified & 2 & 0 & $<20$ & 2 & 0 & $<20$ \\
\hline & 70 & & & 38 & & \\
\hline
\end{tabular}

Agglutination titres of anaerobic rumen organisms with human sera

Eleven of 12 human sera tested had no agglutinins for selected rumen organisms: the exception agglutinated to a titre $>\frac{1}{20}$ the somatic antigens only, of 2 Butyrivibrio strains, 2 Lachnospira and one Lactobacillus strain.

\section{Agglutination reactions of anaerobic rumen bacteria isolated from a different cow}

Organisms isolated from cow D in the same way as from cow A were characterized and motility noted. Of 14 strains examined I 2 gave characteristic patterns of agglutination similar to those of isolates from cow A, when tested with sera from three cows, one goat, horse and rabbit. Two motile strains behaved somewhat differently in that they gave no reaction with the goat and cow A sera although they gave a strong reaction with the sera of cows $D$ and $F$ and with horse serum.

\section{Agglutination reactions of Escherichia coli}

Sixteen strains isolated from the rumen of cows $\mathrm{B}$ and $\mathrm{C}$ showed agglutination patterns against cow A serum similar to those of the motile anaerobic rumen bacteria 


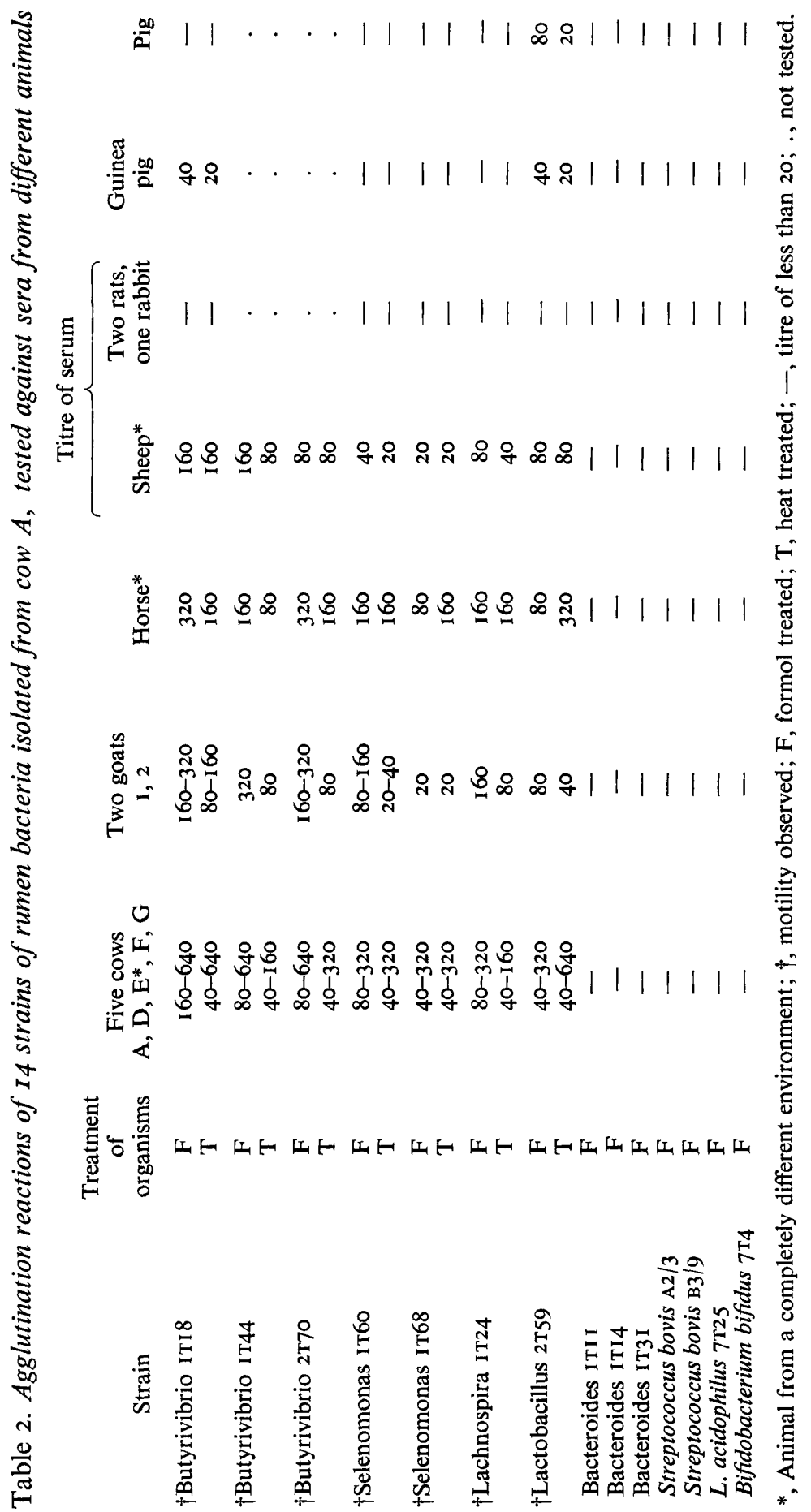




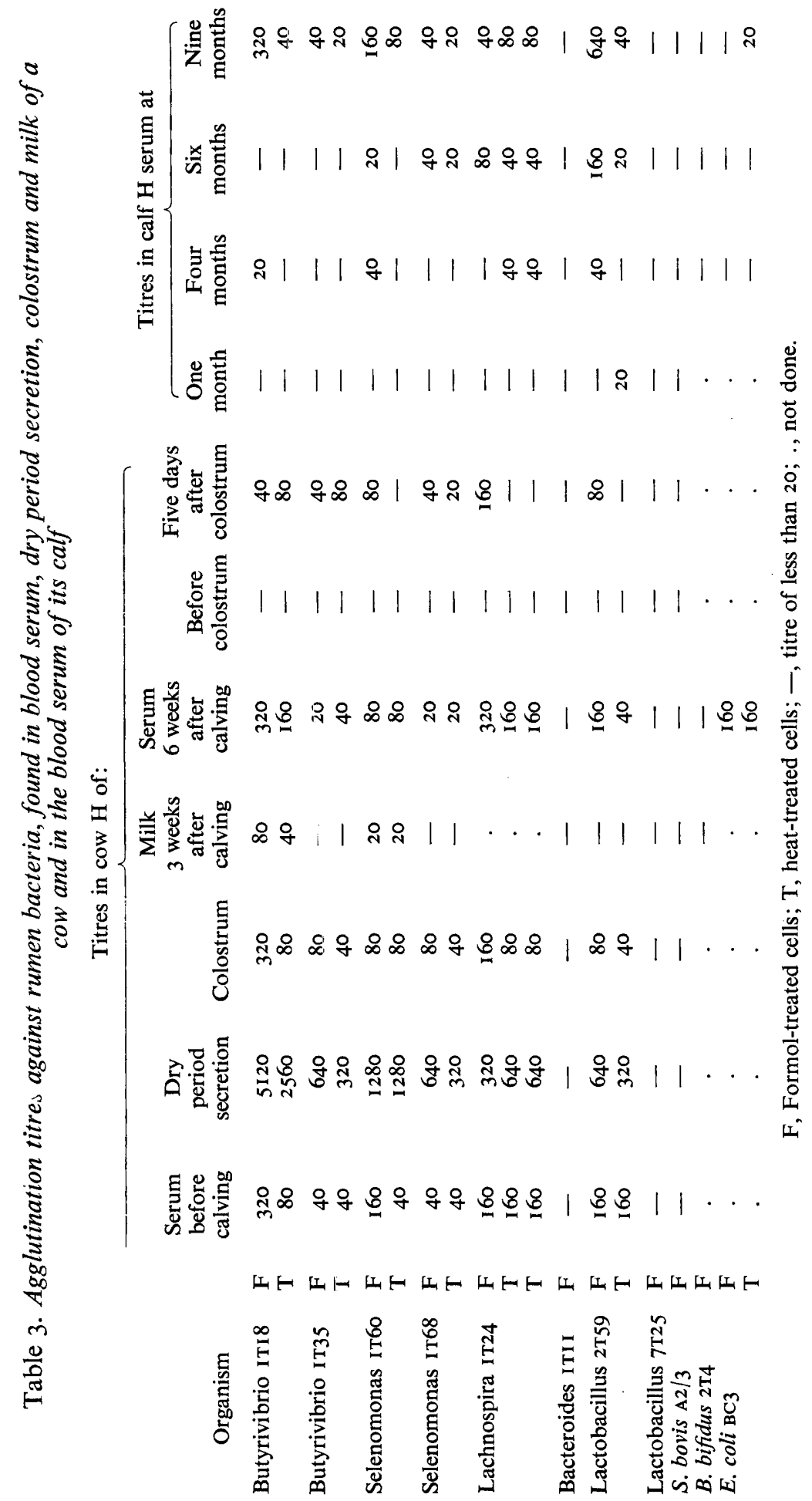


except that no agglutination occurred with the sheep serum but it did occur with the pig serum. Four human strains were not agglutinated by the sera, and two were only weakly agglutinated. Ten non-motile Klebsiella aerogenes strains were not agglutinated.

\section{Serological relationships between strains of rumen bacteria}

Absorption tests showed that the serum of cow A had natural agglutinins specific for many of the organisms, despite some sharing of antigens. Thus there were four different serotypes in five Butyrivibrio strains, with variations in both somatic and flagellar antigens; 3 Selenomonas strains had different antigens, but 2 Lachnospira strains appeared identical. Injection of the organisms into rabbits induced specific somatic and flagella agglutinins.

\section{Retesting serum from cow $A$}

Eleven months later another sample of serum was taken from cow A. During this time the cow had been on several different diets and at the time of sampling was out at pasture. The pattern of agglutination against rumen organisms was similar to that found with the previous sample of serum.

\section{Transfer of naturally occurring antibodies from the cow to the calf}

Table 3 shows the agglutination titres found in one of the three experiments with a cow and its calf. The level of antibodies in the secretion of the non-lactating udder was approximately 8 -fold that of the blood serum, whereas in the colostrum the levels were the same as the serum. In the milk 3 weeks after parturition only a very low level of antibodies could be detected. In serum, 6 weeks after calving the level was similar to that found three weeks before calving. The concentration of these antibodies in the serum of a pregnant cow was therefore the same as in the lactating cow.

No antibodies were detected in the calf $(\mathrm{J})$ serum before colostrum was given, whilst after feeding colostrum for 5 days agglutination titres were detected. However at I month, on a diet of milk and roughage, these passively acquired antibodies had disappeared and even at 3 months the calf had manufactured only traces of its own antibodies against these strains.

In the two other experiments (Cows $F$ and $G$ ) the titres of antibodies in the serum after parturition were similar to the levels in the colostrum. In the milk, levels were again very low. With the two calves $K$ and $L$ the results were similar to calf $J$ except that in one of them $(\mathrm{K})$ the level of absorbed antibodies was much lower than in the other calves although the titres in the mother's serum were as high as in the other two cows. With calf $\mathrm{L}$, which was on a milk diet for 2 months, results were obtained similar to those from the other two on milk and roughage diets.

At 4 months traces of antibodies which agglutinated some of the rumen strains were observed in all three calves. At 6 months the titres had risen, particularly in calf $\mathrm{K}$, where titres against all except one of the normally positive rumen strains varied from 80 to 320 . Eventually, after 9 months, agglutinin patterns similar to those in adult ruminants became established.

To investigate whether the calves developed any antibodies against their own rumen organisms, samples of rumen contents were taken by stomach tube from calves $\mathrm{K}$ 


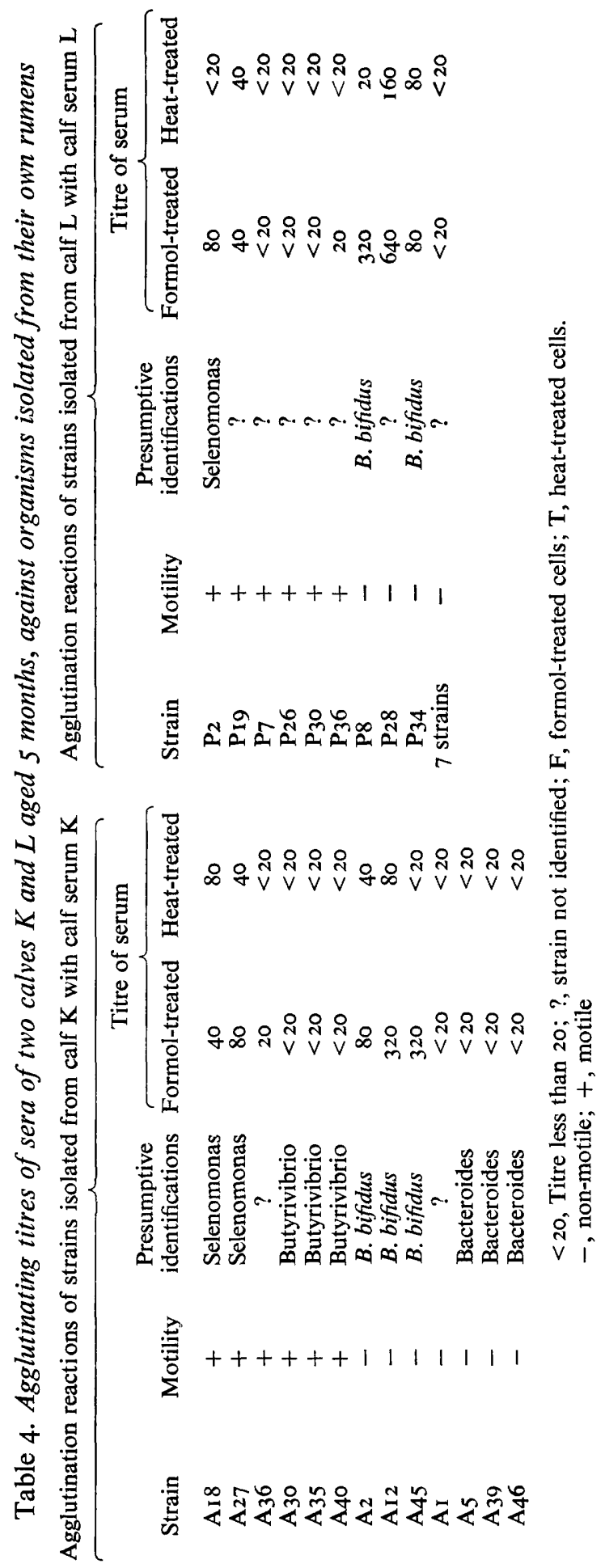


and $\mathrm{L}$ at 5 months of age, organisms were isolated by anaerobic techniques and tested against the calves' own sera. Identification of these organisms was by microscopic appearance and presence or absence of motility only. Table 4 shows that there was not the same correlation between motility and ability to react with antibodies as with the sera of adult ruminants. No agglutinins were observed for some of the motile strains, including some selenomonds, whilst relatively high titres occurred with some non-motile strains, in particular some Bifidobacterium bifidus strains. No antibodies to Bacteroides were observed in calf $\mathrm{K}$, where these organisms were among the majority flora. It thus appears that motility is not a necessary factor to stimulate the formation of antibodies in the calf against its own rumen strains.

\section{Fractionation of serum and colostrum from cow $H$}

One of the physical criteria of natural antibodies is that they are predominantly present in the IgM fraction of immunoglobulins, apparently because of the very low level, but continuous antigenic stimulation (Michael \& Rosen, 1963). Cow serum was chromatographed on Sephadex 200 and the fractions of the first two peaks tested against a Butyrivibrio strain and a Selenomonas strain. All the agglutinating activity for both flagellar and somatic agglutinins appeared in the fraction which was completely excluded from the gel, being contained in the front peak. No agglutinins were found in the later fractions, indicating that the antibodies were of the IgM type, and confirming the findings of previous workers (Landy \& Weidanz, I964). Similar results were obtained with colostrum, which also contained all the agglutinins in the high molecular fractions of the first peak.

\section{DISCUSSION}

The agglutinin titres obtained in bovine serum against rumen bacteria substantiated our suggestion that the high concentration of these organisms might evoke a strong antigenic stimulus. A sensitive bactericidal test (Landy \& Weidanz, 1964) has been used to detect the presence of natural antibodies against Gram-negative bacteria, but the relatively high titres obtained with agglutination tests against the rumen bacteria made such tests unnecessary. The high specificity of the natural agglutinating antibodies in ruminants was shown by absorption tests where, with only Io strains of three different genera, the presence of eight different serotypes was demonstrated. Specificity is further illustrated by the absence of agglutinins against a human Escherichia coli strain although they were detected against a rumen $E$. coli strain. The presence of antibodies against the indigenous rumen flora differentiate the ruminants and the horse from other mammals such as the rat, rabbit, guinea pig, pig and man. Horse serum may contain the same antibodies as the ruminant because microbial digestion of plant residues takes place in the caecum which probably contains similar organisms to those in the rumen (Davies, 1964).

The site of antigenic stimulation against these rumen organisms is unknown. Rumen organisms are transferred almost continuously from the rumen to the omasum and abomasum (Smiles \& Dobson, 1956) so that only small numbers of whole organisms pass to the small intestine. The low $\mathrm{pH}$ of about $2 \cdot 0$ in the abomasum would probably destroy most of the survivors, except lactobacilli and coliforms (Smith, 1965). No information is available on the obligate anaerobic flora of the adult bovine intestine. 
The presence of antibodies in the sera against rumen strains of Escherichia coli, which were only present in very small numbers in the rumen, suggests that they colonize the intestine where antigenic stimulation could occur. Microbial cells may also be translocated across the gut wall and eventually enter the lymph nodes (Wolochow, Hildebrand \& Lamanna, 1966; Grys, 1966). Such translocation might also occur in the rumen wall.

The reason for the selective stimulation in the adult ruminant of antibodies against motile strains only of rumen organisms is not yet clear. Lovell (1932) detected flagellar agglutinins against Salmonella in $67 \%$ of animals examined (horses, cattle, sheep, pigs) so that flagellar antibodies may be widespread. Flagellins are not destroyed by pepsin and trypsin but are rendered soluble at $\mathrm{pH} 2 \cdot 0$ (Kobayashi, Rinker \& Koffler, 1959; Stocker \& Campbell, I959). Solubilized flagellins are antigenic (Fitch \& Winebright, 1962), and could therefore be a source of antigenic stimulation in the intestine. Butyrivibrio fibrisolvens (Bryant \& Small, I956a) is monotrichous; Selenomonas ruminantium (Bryant, I956) has a tuft of lateral flagella; Lachnospira multiparvus (Bryant \& Small, 1956b) has one lateral flagellum. The single flagellum or laterally placed flagella are unlikely to be fixed over the whole cell surface in formolized cultures, and some of the somatic antigens might also be taking part in agglutination.

In the calf strong agglutinins to the non-motile Gram-positive Bifidobacterium bifidus were present. These bifidus organisms are present in much larger numbers in the calf; they were isolated as part of the majority flora in the rumen of all three calves examined aged 3,4 and 5 months respectively. The calf has therefore been subjected to much greater exposure to bifidus than has the adult animal.

As natural antibodies are reported to be of the IgM type, it was to be expected that the agglutinins specific for the rumen organisms would be IgM. The lactating bovine mammary gland is not very permeable to immune globulins, although low agglutinin titres against streptococci, staphylococci and coliforms have been detected in milk (Reiter \& Oram, 1967). During the dry period the gland becomes selective and concentrates the immunoelectrophoretically fast globulins of IgG (Murphy, Aalund, Osebold \& Carroll, 1964; Pierce \& Feinstein, 1965). However IgM has been detected by immunoelectrophoresis in colostrum and in calf serum after feeding colostrum (Popovici \& Jurenkova, 1967; Baglioni \& Fioretti, 1967). Dr W. J. Penhale ((Royal Dick) School of Veterinary Studies, Edinburgh, personal communication and 1965) has made quantitative studies of the concentration of IgM in colostrum and its absorption into the calf serum using purified IgM, IgG; he also found that IgM was absorbed through the calf intestines.

The specific agglutinins against rumen organisms were found to be sensitive markers of the transfer of IgM to the secretion and colostrum and then to the calf serum. Our results show that IgM antibodies against rumen organisms were present in the same concentration in the colostrum as in the blood serum, indicating that there was no selective concentration of this type of immunoglobulin in the udder. The increased titres in the non-lactating secretion compared with those in blood serum are due to physical concentration because of the re-absorption which takes place during drying off. Our results also confirm that in the calf IgM is freely taken up through the gut. 
The authors wish to thank Mr L. G. Newland, Mr B. A. Phillips and Miss Ann Fort for expert technical assistance. They are also grateful to Drs J. H. B. Roy and J. D. Leaver for rearing the three calves used in this work.

\section{REFERENCES}

Baglion,, T. \& FioRetTI, C. (1967). Le immunoglobuline del siero di colostro e di latte bovine indagate con metodo immunolettroforetico. Archo vet. ital. 18, 419.

Boyden, S. V. (1966). Natural antibodies and the immune response. Adv. Immunol. 6. Ed. by F. J. Dixon and H. G. Kunkel. New York and London: Academic Press.

BRYANT, M. P. (1956). The characteristics of strains of Selenomonas isolated from bovine rumen contents. J. Bact. 72, 162.

Bryant, M. P. \& Small, N. (1956a). The anaerobic monotrichous butyric acid producing curved rod shaped bacteria of the rumen. J. Bact. 72, 16.

BRYANT, M. P. \& Small, N. (1956b). Characteristics of two new genera of anaerobic curved rods isolated from the rumen of cattle. J. Bact. 72, 22.

Caldwell, D. R. \& Bryant, M. P. (1966). Medium without rumen fluid for non-selective enumeration and isolation of rumen bacteria. Appl. Microbiol. 14, 794.

Cleland, W. W. (1964). Dithiothreitol, a new protective reagent for SH groups. Biochem. 3, 480.

Davies, M. E. (1964). Cellulolytic bacteria isolated from the large intestine of the horse. J. appl. Bact. 27, 373.

Fitch, F. W. \& Winebright, J. (1962). Antibody formation in the rat. II. Agglutinin response to soluble flagellin from Salmonella typhosa. J. Immun. 89, 900.

Gibson, H. J. (1930). Observations on the occurrence, characteristics and specificity of natural agglutinins. J. Hyg., Camb. 30, 337.

GrYs, S. (1966). The mode of passage of viable Escherichia coli and its antigens across the intestinal barrier of sheep. II. Intracellular localization of bacterial antigens in some internal organs. Pol. Arch. Wet. ro, 243.

Hungate, R. E. (1950). The anaerobic mesophilic cellulolytic bacteria. Bact. Rev. I4, I.

Hungate, R. E. (1966). The Rumen and its Microbes. New York and London: Academic Press.

KobaYASHI, T., RiNKER, J. N. \& KoffLER, H. (I959). Purification and chemical properties of flagellin. Archs Biochem. Biophys. 84, 342.

LANDY, M. \& Wemanz, W. P. (1964). Natural antibodies against Gram negative bacteria. p. 275 in Bacterial Endotoxins: Proc. symp. Rutgers Univ. Ed. by M. Landy and W. Braun. New Brunswick N.J. Rutgers State University.

Lovell, R. (1932). The presence of agglutinins for bacteria of the Salmonella group in the sera of normal animals. J. comp. Path. Ther. 45, 27.

Man, J. C. De, Rogosa, M. \& Sharpe, M. E. (1960). A medium for the cultivation of lactobacilli. J. appl. Bact. 23, $\mathrm{I} 30$.

MichAEL, J. G. \& RoSEN, F. S. (1963). Association of 'natural' antibodies to Gram-negative bacteria with the $\gamma_{\mathrm{I}}$ macroglobulins. J. exp. Med. Ir8, 619.

Murphy, F. A., Aalund, O., Osebold, J. W. \& Carroll, E. J. (1964). Gamma globulins of bovine lacteal secretions. Archs Biochem. Biophys. 108, 230.

Penhale, W. J. (1965). Gamma globulin levels and neonatal mortality in market calves. Vet. Rec. 77, 322.

PierCE, A. E. \& Feinstern, A. (1965). Biophysical and immunological studies on bovine immune globulins with evidence for selective transport within the mammary gland from maternal plasma colostrum. Immunology, 8, 106.

Popovici, D. \& JURENKova, G. (1967). Spectrul imunoelectroforetic al proteinelor serice la vitei in legatura cu capacitaten de aparase. Lucr. Stiiint Inst. Cerc. zooteh. 25, 329.

ReITER, B. \& OrAM, J. D. (1967). Bacterial inhibitors in milk and other biological fluids. Nature, Lond. 216, 328.

Sharpe, M. E., Fryer, T. F. \& Smith, D. G. (I966). Identification Methods for Microbiologists. Ed. by B. M. Gibbs and F. A. Skinner. London and New York: Academic Press. 
Shatтock, P. M. F. (1963). Enterococci. In Chemical and Biological Hazards in Foods. Ed. by J. C. Ayres, H. A. Kraft, H. E. Suyder and H. W. Walker. Ames, Iowa, U.S.A.: Iowa State University Press.

Smiles, J. \& Dobson, M. J. (1956). Direct ultraviolet and ultraviolet negative phase contrast micrography of bacteria from the stomachs of the sheep. Jl R. microsc. Soc. 75, 244.

SMrTH, H. W. (I965). Observations on the flora of the alimentary tract of animals and factors affecting its composition. J. Path. Bact. 89, 95.

Stocker, B. A. D. \& CAmpbell, J. C. (1959). The effect of non lethal deflagellation on bacterial motility and observations on flagella regeneration. J. gen. Microbiol. 20, 670.

Wolochow, H., Hildebrand, G. J. \& Lamanna, C. (I966). Translocation of microorganisms across the intestinal wall of the rat: effect of microbial size and concentration. J. infect Dis. I16, 523 . 